MATAPPA: Jurnal Pengabdian Kepada Masyarakat
Volume 1 | Nomor $1 \mid$ Maret |2018
e-ISSN: $2614-6673$ dan p-ISSN: $2615-5273$
\begin{tabular}{|l} 
CC) (1) This work is licensed under a Creative Commons Attribution \\
4.0 International License
\end{tabular}

\title{
Career Day Bagi Siswa dan Guru SMA Bimbingan Konseling
}

\section{Farida Aryani' ${ }^{1)}$ Muhammad Ilham Bakhtiar ${ }^{2)}$}

Keywords :
Career Day;
Bimbingan konseling;
Dunia kerja.

Corespondensi Author
${ }^{1}$ Universitas Negeri Makassar
Email: farayani77@yahoo.com
${ }^{2}$ STKIP Andi Matappa Pangkep
Email:ilhambakhtiar86@gmail.com

History Artikel

Received: 18-01-2018

Reviewed: 11-02-2018

Revised: $12-03-2018$

Accepted: 10-03-2018

Published: 30-03-2018

\begin{abstract}
ABSTRAK
Tujuan IbM ini untuk memberikan siswa pemahaman dan menilai dirinya terutama potensi yang dimilikinya yang terkait dengan dunia kerja yang akan dipilihnya kelak, dan Siswa mampu merencanakan masa depan secara rasional sesuai dengan potensi dan minat yang dimilikinya. Metode yang digunakan dalam pengabdian kepada masyarakat ini adalah : Metode persentase dan ceramah dan tanya jawab, metode diskusi, metode praktek, tersedia stand karir, Aplikasi e-career, konseling individu untuk konsultasi pilihan karir. Hasil pelaksanaan kegiatan melalui penerapan pemberian kegiatan Career Day bagi Guru dan Siswa berjalan dengan baik, siswa telah memahami dan dapat menilai potensi yang dimilikinya khususnya yang terkait dengan dunia kerja yang akan dipilihnya, Siswa telah mampu merencanakan masa depannya secara rasional sesuai dengan potensi dan minat yang dimilikinya. Guru telah mengetahui pelayanan bimbingan karir di sekolah, guru BK memberikan layanan karir dan menyusun program bimbingan karir, kemudian mampu melakukan praktek-praktek yang telah diberikan, guru BK juga telah mengetahui berbagai jenis-jenis program layanan bimbingan karir yang dapat diterapkan disekolah masing-masing seperti materi karir, perencanaan masa depan, mengenal bakat dan minat lewat tes, implementasi permen 111 tahun 2014 di sekolah serta koordinasi antar stekholder dalam menyelenggarakan kegiatan bimbingan karir atau mengkolaborasikan dengan unsur-unsur yang lain.
\end{abstract}

\section{PENDAHULUAN}

Bimbingan karir merupakan salah satu jenis layanan dari program bimbingan dan konseling. Secara kelembagaan, bimbingan dan konseling itu adalah bagian dari keseluruhan program pendidikan di sekolah, yang ditujukan untuk membantu atau memfasilitasi siswa agar mencapai perkembangan diri yang optimal, jelas diuraikan pada panduan peminatan kurikulum 2013 menjelaskan bahwa untuk menghasilkan generasi yang berkualitas, proses pendidikan perlu ditunjang dengan konseling pendidikan dan konseling karir untuk memastikan bahwa (1) peserta didik mendapatkan kesempatan yang setara untuk mendapatkan pendidikan dan pilihan karir yang layak sesuai dengan minat dan kemampuan mereka; dan (2) pilihan pendidikan dan peminatan karir tersebut berdasarkan minat setiap peserta didik. Dalam hal ini peranan konselor sekolah sangatlah penting untuk membantu peserta didik membuat keputusan karir sesuai minat masing-masing peserta didik. (Kemendikbud.2013).

Di sekolah, siswa dituntut untuk menguasai berbagai kemampuan atau kompetensi, baik yang 
berhubungan dengan mata pelajaran, maupun yang berhubungan dengan pengembangan diri pribadi, sosial dan karir kehidupannya. Agar siswa dapat mencapai perkembangan yang optimal, diperlukan layanan yang optimal pula dari setiap unsur pendidikan di sekolah. Sebagai implementasi dari bidang bimbingan tersebut, maka siswa diharapkan dapat memiliki keterampilan khusus yang dapat diaplikasikan dalam kehidupan sehari-hari yang secara umum telah tergambarkan dalam pekerjaan atau karir.

Siswa kerapkali menemui adanya kesulitan dalam hal karirnya. Bingung menentukan arah karirnya bahkan juga masih bingung mengenai beberapa lowongan pekerjaan, institut/universitas atau profesi lainnya yang ada di lapangan. Dengan begitu, masalah karir siswa dalam pengembangan dan perencanaan karir harus diperhatikan oleh pihak sekolah, baik konselor maupun guru bidang studi. Yang pada hakikatnya, pengembangan dan perencanaan karir tersebut bukan hanya menjadi tugas dari pihak sekolah, akan tetapi orangtua bahkan sampai kepada kalangan mahasiswa juga harus mengambil peran penting.

Data survel awal di lingkup Dinas Pendidikan Kabupaten Sidrap pada SMA Negeri 2 Panjariajang, yang dilakukan melalui wawancara pada guru Bimbingan Konseling, diperoleh informasi bahwa, layanan bimbingan karir kepada siswa melalui career day masih tergolong jarang dilaksanakan, guru masih fokus kepada pencapaian akademik siswa, belajar dan sosialnya namun aspek bimbingan karir belum tersentuh secara khusus. Hal ini disebabkan karena belum adanya kegiatan dan panduan yang dimiliki secara khusus untuk menerapkan kegiatan layanan informasi karir melalui career day. Siswa di sekolah hanya fokus kepada belajar, dan ketika memasuki kelas akhir banyak siswa yang kebingungan akan studi lanjut dan tidak mengetahui cita-cita yang diharapkannya bahkan siswa hanya ikut-ikutan dengan teman kelasnya, sehingga potensi bakat dan minat yang dilimiki siswa tidak dijadikan ukuran dalam memilih karirnya.

Dari data dilokasi IbM terdapat jumlah sekolah SMA/sederajat di kabupaten sidrap adalah 23 yang terdiri dari 9 MA dan 14 SMA dengan jumlah siswa 5.192. Jumlah siswa di kabupaten sidrap tergolong sangat banyak tentunya harus mendapat perhatian khusus dalam mengarahkan peserta didik dalam merencanakan dan mengambil keputusan karirnya. Hasil wawancara kepada salah satu guru di Kabupaten Sidrap mengungkapkan bahwa masih banyak guru bimbingan konseling yang kurang pemahaman tentang layanan infomrasi karir di melalui kegiatan career day, Siswa kerapkali menemui adanya kesulitan dalam hal karirnya, termasuk ketika memilih jurusan, memilih perguruan tinggi, bahkan siswa memilih jurusannya didasari hanya ikut ikutan bukan karena potensi dan bakat yang dimilikinya. Dengan begitu, masalah karir siswa dalam pengembangan dan perencanaan karir harus diperhatikan oleh pihak sekolah, baik konselor maupun guru bidang studi.

Pada hakikatnya, pengembangan dan perencanaan karir tersebut bukan hanya menjadi tugas dari pihak sekolah, akan tetapi orangtua bahkan sampai kepada kalangan akademisi dan pelajar juga harus mengambil peran penting. Maka para guru dan kepala sekolah bersama dengan pelaksana $\mathrm{I}_{b} \mathrm{M}$ ini memandang perlu untuk mengadakan kegiatan pengabdian $\mathrm{I}_{b} \mathrm{M}$ yang melibatkan para guru BK dan siswa pada lokasi tersebut. Kegiatan ini sangat bermanfaat dan memberikan pengaruh yang besar dalam merencanakan karir individu, seperti yang pernah dilakukan oleh (purnamasari, 2006)melalui pelatihan perencanaan karir bagi mahasiswa psikologi dengan metode eksperimen, menghasilkan bahwa ada pelatihan perencanaan karir memberikan sumbangan sebesar $65 \%$ dalam meningkatkan kejelasan arah pilihan bidang minat karir. Hal ini menunjukkan bahwa melalui kegiatan perencanaan karir sangat memberikan peluang besar kepada siswa sebagai pelajar untuk bisa meraih dan memperjelas arah karirnya.

Untuk mengarahkan arah karir siswa di sekolah perlu ada upaya dari guru untuk melakukan kegiatan yang melibatkan siswa dalam memilih dan menetapkan arah karir siswa. Banyak siswa di sekolah yang masih belum mengetahui cita dan harapannya, Kurang mengetahui cara memilih program studi, Kurang mempunyai motivasi untuk mencari informasi tentang karir, Masih bingung memilih pekerjaan, Merasa cemas untuk mendapat pekerjaan setelah lulus Belum memiliki pilihan perguruan tinggi tertentu, jika setelah lulus tidak masuk dunia kerja.(Yusuf:2014)

Berdasarkan permasalahan tersebut diatas maka dipandang perlu melaksanakan kegiatan bimbingan konseling karir dengan nama kegiatan "career day bagi siswa SMA dan Guru- 
Guru. Agar siswa dapat meningkatkan memahami dirinya terutama potensi terkait dengan dunia kerja dan perencanaan arah karir siswa, kemudian guru dapat memberikan layanan bimbingan konseling karir kepada siswa di sekolah.

Tujuan IbM ini untuk memberikan siswa pemahaman dan menilai dirinya terutama potensi yang dimilikinya yang terkait dengan dunia kerja yang akan dipilihnya kelak, dan Siswa mampu merencanakan masa depan secara rasional sesuai dengan potensi dan minat yang dimilikinya.

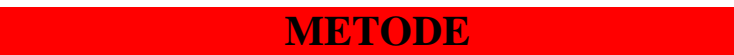

Metode yang digunakan dalam pengabdian kepada masyarakat ini adalah: Metode persentase dan ceramah dan tanya jawab, tersedia stand karir, Aplikasi e-career dapat pula dilakukan metode diskusi, metode praktek (Saman \& Bakhtiar, 2018)

Sebagai upaya yang dianggap tepat dalam membantu siswa untuk memilih karir terutama dalam melanjukan studi, dan memilih pekerjaan yang tepat sesuai potensi dan bakat minatnya adalah dengan memberikan bimbingan karir kepada siswa yang lebih kepada informasi dan cara bersikap terhadap pilihan-pilihan studi dan siap berada ditengah masyarakat untu bekerja. Melihat hal tersebut maka solusi yang ditawarkan adalah memberikan Career Day bagi siswa dan guru di SMA Kabupaten Sidrap. Kegiatan ini dilaksanakan dengan persiapan sebagai berikut:

Persiapan melalui: Kegiatan Survey rencana pelaksanan Career Day, Pemantapan dan penentuan lokasi dan sasaran, Penyusunan bahan dan materi kegiatan

Pelaksanaan pelatihan tersebut dilaksanakan dengan tahap-tahap sebagai berikut. Konseptualisasi merupakan metode penguatan materi yang diberikan kepada siswa dan guru melalui tatap muka: Persentasi, Stand Karir, ter minat bakat melalui Aplikasi

Metode yang digunakan pada kegiatan ini adalah ceramah, praktek konseling karir, dan tanya jawab. Metode ini digunakan dalam hal pemberian materi tentang peluang dan tantangan memilih karir, serta informasi tentang studi lanjut.

Metode Praktek. Metode ini digunakan untuk memfasilitasi siswa dan guru dalam memberikan bimbingan dan koneling karir disekolah. Selain itu, siswa dapat mengunjungi stand yang disediakan untuk melakukan kegiatan ter potensi bakat dan minat kerja.
Setelah kegiatan ini selesai peserta diberi lembar evaluasi untuk melihat tingkat pengetahuan dan kepuasan pada kegiatan ini serta bahan untuk perbaikan pada kegiatan selanjutnya.

Setelah mengikut kegiatan ini, maka para peserta telah memahami materi konsep dan hakikat tentang layanan bimbingan karir, siswa sudah mendapatkan informasi studi lanjut, dapat memutuskan pilihan karirnya, memengatui bakat dan minat kerjanya dan percaya diri atas apa yang dimilikinya saat ini. Guru bimbingan konseling diharapkan dapat menindaklanjuti kegiatan ini pada sekolah masing-masing, serta Guru memberikan penguatan kepada siswa melalui konseling individu dan kelompok dengan topik dan materi tentang karir.

Kegiatan pengabdian pada masyarakat ini mempunyai target luaran yaitu siswa dapat memilih studi lanjut dan merencanakan masa depan, serta guru di sekolah dapat melaksanakan program bimbingan karir bagi siswa. Kegiatan ini dilaksanakan dengan pemberian materi, praktek, diskusi, klinik carer. Peserta akan mampu mengambil keputusan karir dalam memilik pekerjaan, melanjutkan perkuliahan dan menetapkan cita-citanya. Guru sudah mampu membimbing dan mendidik siswa dalam mengarahkan keputusan karirnya.

Tim pelaksana kegiatan ini adalah pelaksana IbM yang merupakan Dosen Jurusan bimbingan dan konseling. Latar belakang pendidikan Ketua dan Anggota tim pengusul IbM PPM ini berfokus pada aspek psikologi pendidikan, konseling, pengembangan diri individu, serta pelatihan-pelatihan pengembangan diri yang sering dilakukan. Selain itu juga masing-masing Ketua dan Anggota tim pelaksana $\mathrm{I}_{\mathrm{b}} \mathrm{M}$ PPM memiliki jadwal dan materi untuk melakukan pengabdian, dimana ketua tim pelaksana memiliki waktu yang relatif lebih lama yaitu kurang lebih 15 jam sedangkan anggota tim memiliki waktu kurang lebih 10 jam dalam memaparkan materi tentang "career day" minat kerja, arah pilihan karir dan informasi perguruan tinggi bagi siswa, sehingga didalam melaksanakan kegiatan ini sangat dimungkinkan untuk dilaksanakan oleh tim IbM PPM.

\section{HASIL DAN PEMBAHASAN}

Pelaksanaan $\mathrm{I}_{\mathrm{b}} \mathrm{M}$ Career Day ini berlangsung selama dua hari Sabtu dan Minggu tanggal 5-6 Maret 2016 di Aula Gedung SMA 
Negeri 2 Pancariajang Kabupaten Sidrap. Diikuti sebanyak 50 orang dari Guru-Guru Bimbingan Konseling dan Kepala Sekolah Tingkat SMP/SMA dan SMK Sederajat Se-Kabupaten Sidrap. Penyajian materi Career Day diawali pembukaan oleh Kepala Dinas Pendidikan Kabupaten Sidrap.

Penyajian materi Career Day berjalan lancar, seluruh peserta hadir dan sangat antusias dalam kegiatan tersebut, hal tersebut terlihat dari berbagai peserta yang memberikan umpan balik baik pertanyaan maupun pendapat pada setiap penyajian materi yang diberikan oleh narasumber. Pada hari pertama peserta diberikan pengantar kegiatan pengabdian tentang tujuan pelaksanaan $\mathrm{I}_{\mathrm{b}} \mathrm{M}$ Career Day Bagi Siswa dan Guru SMA Bimbingan dan Konseling. Peserta mendapat gambaran terkait pelaksanaan kegiatan ini, materi konsep dan hakikat tentang layanan bimbingan karir di sekolah.

Melalui materi ini, guru memahami pelayanan bimbingan karir di sekolah, peran guru BK dalam memberikan layanan karir dan menyusun program bimbingan karir, kemdian praktek-praktek yang diberikan akan menjadi landasar guru BK dalam mengimplementasikan di sekolah, guru BK juga telah mengetahui berbagai jenis-jenis program layanan bimbingan karir yang dapat diterapkan disekolah masingmasing seperti materi karir, perencanaan masa depan, mengenal bakat dan minat lewat tes, implementasi permen 111 tahun 2014 di sekolah serta koordinasi antar stekholder dalam menyelenggarakan kegiatan bimbingan karir atau mengkolaborasikan dengan unsur-unsur yang lain.

Bimbingan karir bagi siswa diberikan sejak saat ini akan membantu dalam merencanakan masa depan siswa, serta memberikan penguatan tentang arah pilihan karir cita-cita yang sesuai dengan bakat dan minat yang ada pada dirinya. Pentingnya informasi dunia kerja sangat mempengaruhi kepercayaan dirinya dalam mengambil keputusan. Minat jurusan yang telah ditempati siswa dapat dimanfaatkan dengan baik melalui pelajaran yang diberikan.

Peserta semakin bersemangat dalam pelatihan tersebut ketika memasuki hari kedua pelatihan. Setelah pemberian materi tentang penempatan dan peminatan karir siswa, dilanjutkan dengan kunjungan stand pameran yang disiapkan panitia stand ini terdiri dari berbagai jenis yaitu informasi perguruan tinggi, konsultasi karir, tips merencanakan masa depan, serta layanan tes minat karir bakat siswa.

Peserta yang telah mengikuti tes karir, dapat mengkonsultasikan langsung pada konselor yang telah disiapkan. Tujuannya yaitu memberikan penguatan dan penjelasan terhadap hasil yang diperolehnya. Alat tes ini bernama "Tes Bakat Minat Anak" yang terdiri dari Tes Mengenal diri, Multiple intelegensi, minat kerja. Sebelum penutupan tim IbM memberikan refleksi dalam bentuk tanya jawab untuk melihat tanggapan mereka terkait dengan kegiatan Career day ini di berikan.

Bimbingan karir merupakan suatu proses membantu pribadi untuk mengembangkan penerimaan kesatuan dan gambaran diri serta peranannya dalam duria kerja. Donal dalam batasan ini, ada dua hal penting dalam bimbingan karir, pertama proses membantu individu untuk memahami dan menerima diri sendiri, dan kedua memahami dan menyesuaikan diri dalam dunia kerja. Donald D. Super (1975). Melalui bimbingan karir maka siswa sebagai individu yang mengalami proses perkembangan kematangan, dapat mengenal dirinya, memahami dirinya, dan mengenal dunia kerja serta merencankan masa depan dengan bentuk kehidupan yang diharapkan untuk menentukan pililian dan mengambil suatu keputusan bahwa keputusannya tersebut adalah paling tepat sesuai dengan keadaan dirinya dihubungkan dengan persyaratanpersyaratan dan tuntutan pekerjaan/ karir yang dipilihnya. Dengan bimbingan karir yang diberikan tentun Siswa dapat memiliki dan bekesempatan yang sama untuk mengembangkan dirinya dalam pencapaian kariernya secara tepat. Pengambilan keputusan didasari dari potensi dan bakat yang dimilikinya sehingga tidak ada perkecualian dalam mengambil keputusan yang tepat.

Guru bimbingan dan konseling memiliki peran yang sangat besar dalam mengarahkan dan membimbing siswa untuk mengambil keputusan karirnya termasuk cita-cita maupun pekerjaan. Undang-Undang Republik Indonesia Nomor Tahun 2003 tentang Sistem Pendidikan Nasional menentukan bahwa bimbingan dan konseling (BK) sebagai bagian integral dari sistem pendidikan. Para guru BK atau konselor menawarkan layanan BK untuk membantu peserta didik dalam mengoptimalkan perkembangan individual mereka, termasuk 
dukungan untuk membuat pilihian yang terkait dengan pekerjaan.

Pelaksanaan IbM Career Day menunjukkan hasil yang sangat baik, guru memiliki manual program yang telah diberikan untuk diterapkan disekolah. Baik secara individu maupun kelompok diantaranya kegiatan bimbingan konseling denganmemberikan materi secara klasikal pentingnya mengenal dan merencanakan masa depan untuk karir yang lebih baik.

Kegiatan ini dihadiri 50 orang dari berbagai kalangan jenjang pendidikan di Kabupaten Sidrap telah memahami materi dan mampu menyusun program bimbingan karir berbasis kebutuhan sekolah. Terdapat $93 \%$ guru telah memahami materi yang diberikan melalui angket sederhada yang disebarkan oleh panitia.

Selain itu, Siswa telah mampu mengenal dan memahami potensi dan bakat yang dimilik dirinya, hal ini terlihat dari hasil tes minat bakat karir yang diberikan kepada siswa. Serta siswa telah mengenal dunia kerja dan mampu merencankan masa depan dengan baik, karena hasil tes tersebut dikonsultasikan kembali kepada konselor yang disiapkan. Diharapkan dalam menentukan pilihan dan mengambil suatu keputusan yang tepat telah sesuai dan sangat memilki kepercayaan diri karena keputusan itu lahir dari pertimbangan yang jelas. Dengan bimbingan karir yang diberikan tentun Siswa dapat memiliki dan berkesempatan yang sama untuk mengembangkan dirinya dalam pencapaian prestasi karirnya.

\section{SIMPULAN DAN SARAN}

Dari pelaksanaan kegiatan disimpulkan bahwa penerapan pemberian kegiatan Career Day bagi Guru dan Siswa berjalan dengan baik, siswa telah memahami dan dapat menilai potensi yang dimilikinya khususnya yang terkait dengan dunia kerja yang akan dipilihnya, Siswa telah mampu merencanakan masa depannya secara rasional sesuai dengan potensi dan minat yang dimilikinya. Guru telah menetahui pelayanan bimbingan karir di sekolah, guru BK memberikan layanan karir dan menyusun program bimbingan karir, kemudian mampu melakuka praktek-praktek yang telah diberikan, guru BK juga telah mengetahui berbagai jenisjenis program layanan bimbingan karir yang dapat diterapkan disekolah masing-masing seperti materi karir, perencanaan masa depan, mengenal bakat dan minat lewat tes, implementasi permen 111 tahun 2014 di sekolah serta koordinasi antar stekholder dalam menyelenggarakan kegiatan bimbingan karir atau mengkolaborasikan dengan unsur-unsur yang lain.

Pelaksanaan kegiatan career day disarankan guru dapat mengimplementasikan sesuai kebutuhan disekolah. Kepala sekolah sebagai pengambil kebijakan menberikan dukungan baik material maupun moril demi berjalannya kegitana tersebut. Siswa yang hadir tentunya diharapkan dapat menjadikan kegiatan ini sebagai wadah dalam mengambil keputusan akan cita cita atau karirnya dimasa yang akan datang.

\section{DAFTAR RUJUKAN}

Undang-undang (UU) nomor 20 tahun 2003 tentang Sistem Pendidikan Nasional

Permendikbud No. 111 tahun 2014 tentang Bimbingan dan Konseling pada Pendidikan Dasar dan Pendidikan Menengah

Purnamasari, Alfi. (2006). Efektivitas Pelatihan Perencanaan Kariruntuk Meningkatkan Kejelasan Arah Pilihan Bidang Minat Karir Pada Mahasiswa Semester Iii Fakutas Psikologi. Jurnal Humanitas : Indonesian Psychological Journal Vol. 3 No. 1 Januari 2006 hal.38 49.

purnamasari, A. (2006). UNTUK MENINGKATKAN KEJELASAN ARAH PILIHAN BIDANG Alfi Purnamasari. Humanitas: Indonesian Psychological Journal, $3(1), 38-49$.

Schultze, N. G. (2006). Success factors in Internet-based psychological counseling. CyberPsychology \& Behavior, 9(5), 623-626.

Saman, A., \& Bakhtiar, M. I. (2018). Karya Tulis Ilmiah Bagi Mahasiswa STKIP Andi Mattappa Pangkep. Jurnal Terapan Abdimas, 3(1), 39-43. doi:http://doi.org/10.25273/jta.v3i 1.2165 
MATAPPA: Jurnal Pengabdian Kepada Masyarakat.

Kemendikbud. (2013). Pedoman Peminatan Kurikulum 2013. Jakarta: Kementerian Pendidikan dan Kebudayaan.

Super Donald D. (1975). Career Development self concept theory college entrance examination board. New york

Winkel, W.S. (1997). Bimbingan dan Konseling di Institusi Pendidikan. Jakarta: PT Gramedia 